\title{
Gyrodinium undulans Hulburt, a marine dinoflagellate feeding on the bloom-forming diatom Odontella aurita, and on copepod and rotifer eggs
}

\author{
G. Drebes ${ }^{1} \&$ E. Schnepf ${ }^{2}$ \\ ${ }^{1}$ Biologische Anstalt Helgoland, Wattenmeerstation Sylt; D-25992 List/Sylt, Germany \\ ${ }^{2}$ Zellenlehre, Fakultät für Biologie, Universität Heidelberg; Im Nevenheimer Feld 230. \\ D-69120 Hejdelberg, Germany
}

\begin{abstract}
The marine dinoflagellate Gyrodinium undulans was discovered as a feeder on the planktonic diatom Odontella aurita. Every year, during winter and early spring. a certain percentage of cells of this bloom-forming diatom, in the Wadden Sea along the North Sea coast, was regularly found affected by the flagellate. Supplied with the food diatom $O$. aurita the dinoflagellate could be maintained successfully in clonal culture. The vegetative dife cycle was studied, mainiy by light microscopy on live material, with special regard to the mode of food uptake. Food is taken up by a so-called phagopod, emerging from the antapex of the flagellate. Only fluid or tiny prey material could be transported through the phagopod. Larger organelles like the chloroplasts of Odontella are not ingested and are left behind in the diatom cell. Thereafter, the detached dinoflagellate reproduces by cell division, occasionally followed by a second division. As yet, stages of sexual reproduction and possible formation of resting cysts could not be recognized, neither from wild material nor from laboratory cultures. Palmelloid stages (sometimes with a delicate wall) occurring in ageing cultures may at least partly function as temporary resting stages. The winter species $G$. undulans strongly resembles Syltodinium listii, a summer species feeding on copepod and rotifer eggs. Surprisingly, in a few cases this prey material was accepted by G. undulans as well, at least under culture conditions. When fed with copepod eggs, the dinoflagellate developed into a large trophont, giving rise thereafter by repeated binary fission to 4,8 or 16 flagellates, as a result of a single feeding act. A re-examination of both species under simultaneous culture conditions is planned.
\end{abstract}

\section{INTRODUCTION}

In late winter and early spring, the bloom-forming centric diatom Odontella aurita (Lyngb.) Agardh is a prominent primary producer in the phytoplankton of the German Bight in the North Sea (Drebes, 1974; Drebes \& Elbrächter, 1976, listed under the synonym Biddulphia aurita [Lyngb.] Bréb.). For several years we have regularly found a more or less large portion of dead cells of $O$. aurita that have obviously been killed by a hitherto unknown predator. The chloroplasts of the dead cells were discoloured, having taken on a greenish hue, and were clumped together. The otherwise empty cells contained a thin snorkel-like tube, seldom more than one, which passes the frustule and opens near the aggregated chloroplasts.

In laboratory experiments using a clonal culture of $O$. aurita enriched with wild phytoplankton material supposed to contain also the sought predator, we happened to 
find the culprit for the cell damage described above. It was a dinoflagellate, namely Gyrodinium undulans Hulburt, sucking on cells of $O$. aurita. Both the predator and food species could be maintained successfully in culture. Thus, we were able to study the mode of food uptake and the development of $G$. undulans. Culture experiments showed that $O$. aurita is not the only food source for the dinoflagellate. Surprisingly, as described below, eggs of copepods and rotifers are likewise sucked out.

\section{MATERIALS AND METHODS}

The dinoflagellate Gyrodinium undulans was originally obtained from plankton samples collected on February 20th, 1997, in the Wadden Sea near List/Sylt (German Bight, North Sea). The water temperature measured during sampling was $2.5^{\circ} \mathrm{C}$. Then, four days later, the species was discovered in a raw culture of this wild phytoplankton material mixed up with a clonal culture of the diatom Odontella aurita. A single specimen of $G$. undulans was isolated to serve as a clone. Together with the food species $O$. aurita it could be maintained in laboratory cultures. Using plastic Petri dishes the species was cultivated in Met medium (Schöne \& Schöne, 1982) supplemented with $\mathrm{Na}_{2} \mathrm{SiF}_{6}$, generally at a temperature of $6^{\circ} \mathrm{C}$, under a $10 \mathrm{~h}$ light $/ 14 \mathrm{~h}$ dark regime, with a light intensity of $8-10 \mu \mathrm{mol} \mathrm{m} \mathrm{m}^{-2} \mathrm{~s}^{-1}$.

In order to test for other possible food sources for $G$. undulans apart from diatoms, we isolated eggs of copepods and rotifers from plankton samples of the nearby Wadden Sea. These experiments were carried out under culture conditions different from those described above, namely at $16^{\circ} \mathrm{C}, 14: 10$ hours light-dark regime, and $14 \mu \mathrm{mol} \mathrm{m}^{-2} \mathrm{~s}^{-1}$ illumination.

The living organisms and their developmental stages were studied by light microscopy (LM) using mainly seawater immersion objectives (Leitz). Samples fixed with formaldehyde were also investigated and additionally prepared for scanning electron microscopy (SEM). Infected chains of $O$. aurita were placed onto a millipore filter and treated for $10 \mathrm{~min}$ in $30 \%$ ethanol. The filter was transferred into a dimethoxypropane solution acidified with $\mathrm{HCl}$ for $15 \mathrm{~min}$, and then again treated with dimethoxypropane for addional $30 \mathrm{~min}$. After critical point drying and sputtering with gold-palladium, micrographs could be made on a Zeiss DSM $940 \mathrm{~A}$.

\section{RESULTS}

For several years, during winter and early spring, between December and April, we have regularly found in plankton samples taken from the Wadden Sea at List/Sylt a fairly large number of cells of Odontella aurita sucked out, as we now know, by Gyrodinium undulans. During this annual period the water temperatures in the North Frisian Wadden Sea ranged between $-1{ }^{\circ} \mathrm{C}$ and $6{ }^{\circ} \mathrm{C}$. The percentage of $O$. aurita cells attacked by the dinoflagellate varied considerably in the different years, viz. only about $1 \%$ in 1995 and 1996, but up to $5 \%$ in 1994. Epidemic dimensions were reached on February 27 th, 1997, when $85 \%$ (determined from 1000 cells) of the Odontella population was damaged by $G$. undulans. The water temperatures were at that time $4{ }^{\circ} \mathrm{C}_{i}$ in the following weeks the rate of dead $O$. aurita cells decreased, though the diatom was again blooming. 
The Odontella cells killed by $G$. undulans are easily recognized by the aggregation of the chloroplasts and their greenish discolouration, and by the presence of a snorkellike feeding tube, here called phagopod, which is left behind when the feeding process is finished (see below). The question whether $G$. undulans may be capable of feeding also on other diatom species can be answered negatively. Based on many observations received from a phytoplankton monitoring program of the Wadden Sea near Sylt from 1987-97 (Drebes \& Elbrächter, unpubl.), there was no indication of $G$. undulans preying on other diatoms besides $O$. aurita. Even the morphologically closely related $O$. aurita var. minima (Grunow) Drebes nov. comb.(Basionym: Biddulphia aurita var. minima Grunow), which occurs together with the main species but only in small numbers, was not affected. Phytoplankton species other than diatoms likewise did not seem to serve as food substrate.

Since $G$. undulans strongly resembles Syltodinium listii Drebes, which preys on eggs of copepods and rotifers during the summer season, we supplied our Gyrodinium cultures also with these eggs. Surprisingly, as will be shown below in detail, some eggs were attacked and sucked out.

\section{The free-swimming stage of Gyrodinium undulans}

Substantially in accordance with the original description by Hulburt (1957), the motile flagellates (Fig. 2) are elliptical, slightly dorso-ventrally flattened, and with nearly equally sized epicone and hypocone. The cell size varies between $20-40 \mu \mathrm{m}$ in length and 15-30 $\mu \mathrm{m}$ in width. The epicone has a hemispherical or conical shape, with a rounded apex, the hypocone is hemispherical to truncate-pyramidal, with an oblique, rounded or flattened antapex. The deep and wide girdle is displaced 0.2 the body length, the distinct sulcus extends from apex to antapex and forms a bi-sigmoid curve (Fig. 3). The transverse flagellum encircles the body completely, and the longitudinal flagellum measures one body length, occasionally even more. The nucleus, ca $18 \mu \mathrm{m}$ in diameter, lies in the epicone, generally at the right side above the girdle region. The large and roundish nucleus is a typical dinokaryon showing numerous elongate interphase chromosomes already in the living stage by LM observation. Chloroplasts are absent, the protoplast appears colourless. Well fed flagellates are crowded with highly refractive granules of reserve materials in form of large grains (Fig. 25).

\section{Gyrodinium undulans feeding on Odontella aurita}

\section{Attachment and penetration}

Cells of $O$. aurita are united to form long chain-like colonies. A $G$. undulans flagellate may attach to any site of the diatom: to a valva (Figs 7, 8), to a girdle covering the protoplast (Fig. 1), or to an older girdle connecting sibling cells within a colony chain. In order to drive a feeding tube into the cell interior of the diatom, the flagellate sticks to the frustule with its antapex, and from there a short tubule protrudes - the initial phagopod. Maintaining a firm connection with the outer surface of the frustule, the phagopod broadens to a flat appressorium with a diameter of $2.5 \mu \mathrm{m}$ (Figs 8,9 ). Its open centre is placed directly over an areolar chamber of the siliceous diatom wall (frustule). This can be seen 


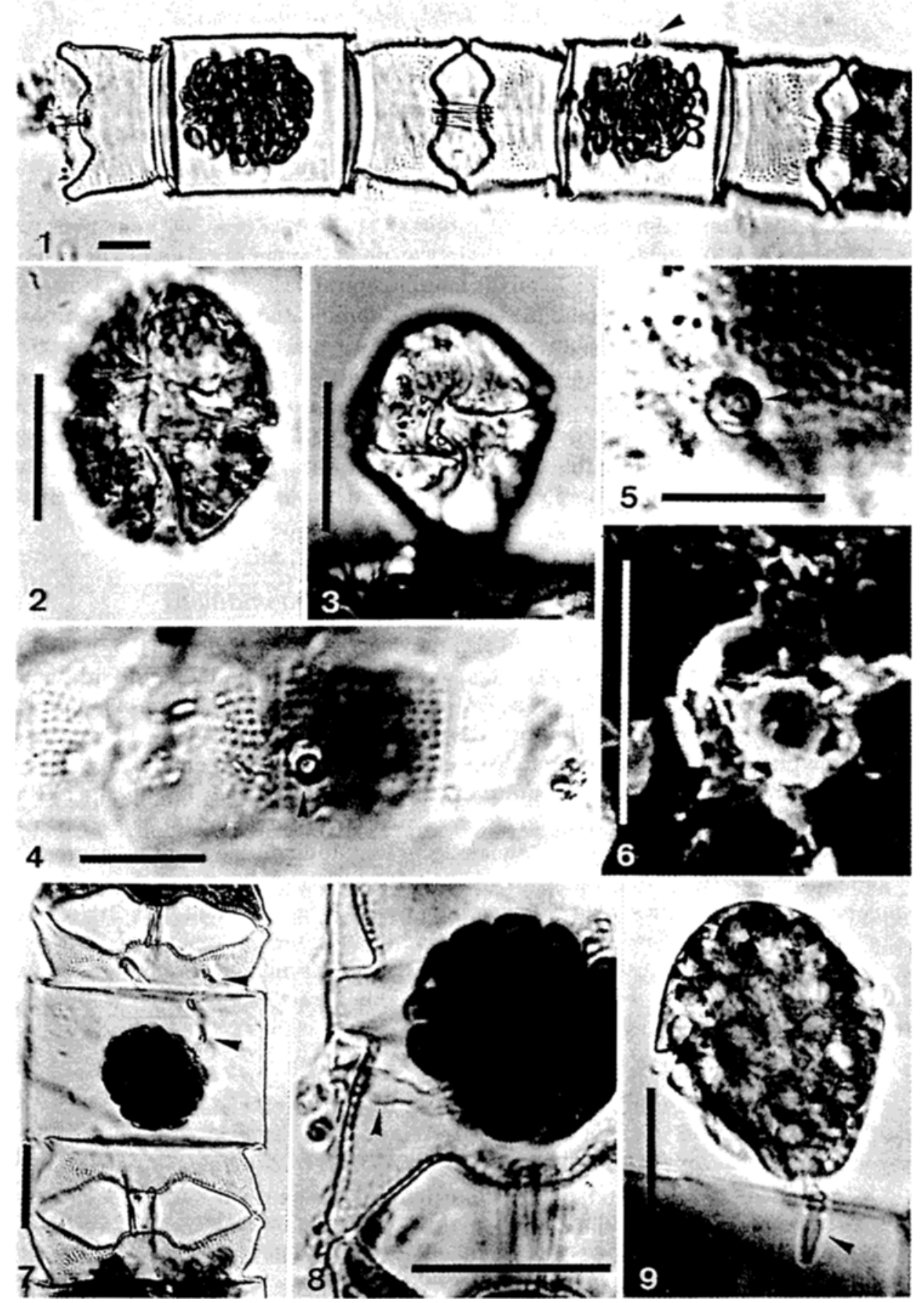

Figs 1-9. Gyrodinium undulans on Odontella aurita; LM: Figs 1-5, 7-9; SEM: Fig. 6. Fig. 1. Chain of $O$. aurita with two cells killed by $G$. undulans, phagopod (arrowhead). Fig. 2. G. undulans, motile stage. Fig. 3. G. undulans, attached stage, ventral view. Figs 4, 5. Appressorium of the phagopod placed above a valvar areola (arrowhead). Fig. 6. Appressorium at high magnification. Fig. 7. Long, twisted, phagopod (arrowheads) penetrating from the valvar face. Fig. 8. Short phagopod (arrowhead) penetrating from the valvar mantle. Fig. 9. Developing phagopod (arrowhead) still closed at the tip. Scale bars: $20 \mu \mathrm{m}$ in Figs 1-3, 7-9; $10 \mu \mathrm{m}$ in Figs 4, 5; $1 \mu \mathrm{m}$ in Fig. 6 
when emptied cells with phagopods left behind are carefully inspected by LM (Figs 4,5), and also by SEM (Fig. 6). The frustule is pierced by the phagopod through the areola which has a diameter of only $0.1-0.25 \mu \mathrm{m}$. Having passed the areola the phagopod usually widens, ampulla-like (Figs 8,9 ), and then elongates to form an approx. 2- $\mu$ m wide tube. The developmental process as well as the subsequent food uptake is difficult to follow in the living stage, because the dinoflagellates react sensitively to illumination during observation.

Not each attachment results in a successful development of a complete phagopod. In cultures, we observed up to four appressoria on a single Odontella aurita cell, only one of which, however, developed into a complete phagopod. It appears that, at least in this case, the various attempts at invading the diatom cell are carried out by the same Gyrodinium undulans flagellate, as seen in Petri dishes containing only very few dinoflagellates. However, successful multi-infections of the same cell cannot be excluded.

The protoplast of the diatom retracts from the site of penetration (Figs 11-14). The elongating phagopod with its still closed conical tip follows the retraction (Fig. 9). If the dinoflagellate has attached to the flat side of the girdle region of a small cell, the phagopod remains straight and short. In this case, the retracting protoplast cannot escape well enough. In other cases, especially when the valva is pierced, the phagopod gains an irregularly twisted, snorkel-like structure (Fig. 7). In large $O$. aurita cells the phagopod may reach a length of more than $60 \mu \mathrm{m}$.

If "old" girdles connecting two neighbouring cells are pierced, the phagopod develops into a long, coiled tube between the two valvae, which are, in this case, not penetrated. Then the phagopod tip does not open.

The phagopod stains with Calcofluor White indicating that the wall of the feeding tube contains cellulose or similar fibrillar polysaccharides.

\section{Food uptake - the prey (diatom)}

The contracted protoplast of the diatom is surrounded by the plasma membrane, which is eventually pierced by the tip of the phagopod. Initially, the plasma membrane does not break down upon penetration (Figs 14-16). The phagopod opens at its tip to form a funnel with an outer diameter of 3-4 $\mu \mathrm{m}$, and an irregular rim, best seen when the feeding process is finished (Fig. 10).

The contents of the protoplast are partially sucked out. Only a clear fluid runs through the narrow lumen of the phagopod. It may consist of cytosol and small organelles. The chloroplasts, however, are left behind. In healthy cells they are bilobed, about $8 \mu \mathrm{m}$ in diameter and $2 \mu \mathrm{m}$ thick. Obviously, these chloroplasts are mechanically so robust that they cannot be deformed to fit into the opening of the phagopod. Soon after the attack they shrink and become more compact with a boat-like shape and elevated rims (Figs 11-16). Finally, when the plasma membrane of the protoplast is broken, they are $5 \mu \mathrm{m}$ long, $3 \mu \mathrm{m}$ wide, and $3 \mu \mathrm{m}$ thick (Figs 17, 18).

The time span between successful attachment and breakdown of the plasma membrane may vary considerably, from about $30-60 \mathrm{~min}$, in general, and up to two hours. Nevertheless, the food uptake may continue for some time, taking in total about $1.5-3 \mathrm{~h}$ (Figs 11-18). The chloroplasts in the disintegrating protoplasts change colour, becoming deep brown-green. Finally, an emptied cell of Odontella aurita shows the characteristic central aggregation of deformed and now greenish discoloured chloroplasts, and a persistent 

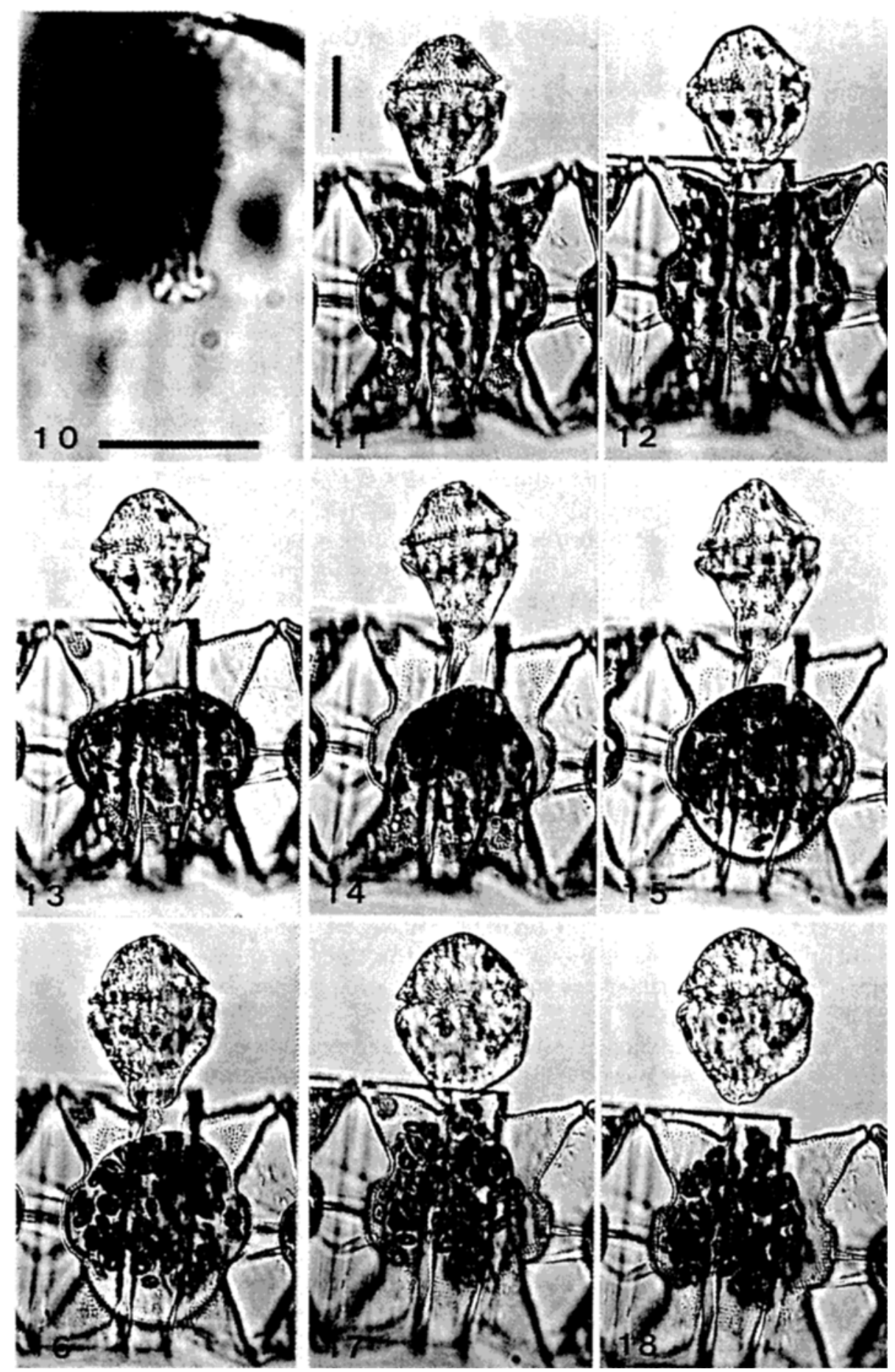

Figs 10-18. Gyrodinium undulans on Odontella aurita; LM. Fig. 10. Distal opening of a phagopod. Figs 11-18. Sequential observation of a feeding process. Fig. 11 . Recently attached flagellate, $11.20 \mathrm{~h}$. Fig. 12. Retracting protoplast of Odontella, $11.26 \mathrm{~h}$. Fig. 13. Retraction continued, $11.30 \mathrm{~h}$. Fig. 14. Flagellate's hypocone tapered, $11.42 \mathrm{~h}$. Fig. 15. Diatom protoplast rounded, feeding started, $11.50 \mathrm{~h}$. Fig. 16. Feeding continued, chloroplasts deformed, $12.29 \mathrm{~h}$. Fig. 17. Membrane of the diatom protoplast broken, $13.21 \mathrm{~h}$. Fig. 18 . Flagellate detached, $13.23 \mathrm{~h}$. Scale bars: $20 \mu \mathrm{m}$ 
phagopod (more exactly its wall) left behind. The destruction of the cells by Gyrodinium undulans does not lead to a rupture of the colony chain (Fig. 1).

\section{Food uptake - the predator (dinoflagellate)}

During food uptake the hypocone of the attached dinoflagellate changes in shape, forming a slender, truncate cone (Figs 11-15). The phagopod terminates proximally in the antapex of the trophont. From here small food vacuoles originate, enlarge to a size of $4 \mu \mathrm{m}$, and then detach (Figs 19, 20). Initially, the development and separation of the food vacuoles takes only $20-40 \mathrm{sec}$ each, and slows down to $30 \mathrm{~min}$ towards the end. The detached food vacuoles migrate along the sulcal region to fuse with an inconspicuous digestion vacuole, which lies in the hypocone near the girdle.

The digestion vacuole does not increase in size all the time. There is obviously an equilibrium between import via food vacuoles and export of digested material into the cytoplasm, of membrane material, and of water. Soon after food uptake has started, highly refractive, irregularly shaped storage granules arise in the cytoplasm and fill the cell. Both flagella of the trophont remain present but show no motion.

When feeding comes to an end, the hypocone rounds up (Figs 16-18). The connection between the antapex of the flagellate and the external part of the phagopod becomes interrupted. The liberated trophont packed with storage granules shows initially no or only sluggish movement, and finally divides by cell division. Often the daughter cells stick together for some time and move as "twins" through the water column. Rarely, a second cell division may follow, since occasionally cell quadruplets can be observed. Certainly depending on the amount of food taken up, a subsequent cell division does not seem obligatory. This may be the case especially after a multi-infection, when the flagellates have to share the food material. Then, the detached flagellates remain undivided and are again capable of attacking another Odontella cell, frequently one near by.

The remnants of $O$. aurita cells killed by Gyrodinium undulans are thereafter normally utilized by bacteria. Additionally, a Pirsonia-like nanoflagellate could be frequently observed taking up the greenish discoloured chloroplasts, which G. undulans had left behind in the diatom cell (Drebes, unpubl.).

\section{Gyrodinium undulans feeding on copepod and rotifer eggs}

Owing to its morphological similarity with Syltodinium listii, which feeds on eggs of copepods (Temora, Acartia, Pseudocalanus) and rotifers (Synchaete sp.), we offered a similar food material to Gyrodinium undulans. Although the material was sparse in March - at low water temperatures of $3.7-5.3^{\circ} \mathrm{C}$, we could isolate from net hauls a few eggs of the planktonic calanoids Pseudocalanus elongatus Boeck, Temora longicornis Müller, of the benthonic harpacticoid Parastenocaris sp., and of an undetermined rotifer (cf. Synchaete). Brought together with $G$. undulans, the results of the feeding experiments were different and at present are still preliminary (Figs 21-24). Studying the smooth-walled eggs of Pseudocalanus elongatus, we observed at first a successful attack and food uptake by Gyrodinium, and the same occurred when eggs of Parastenocaris and cf. Synchaete were offered. In the case of Temora eggs, however, the development into nauplii was obviously faster than a possible infection by Gyrodinium. Whether the flagellate is 

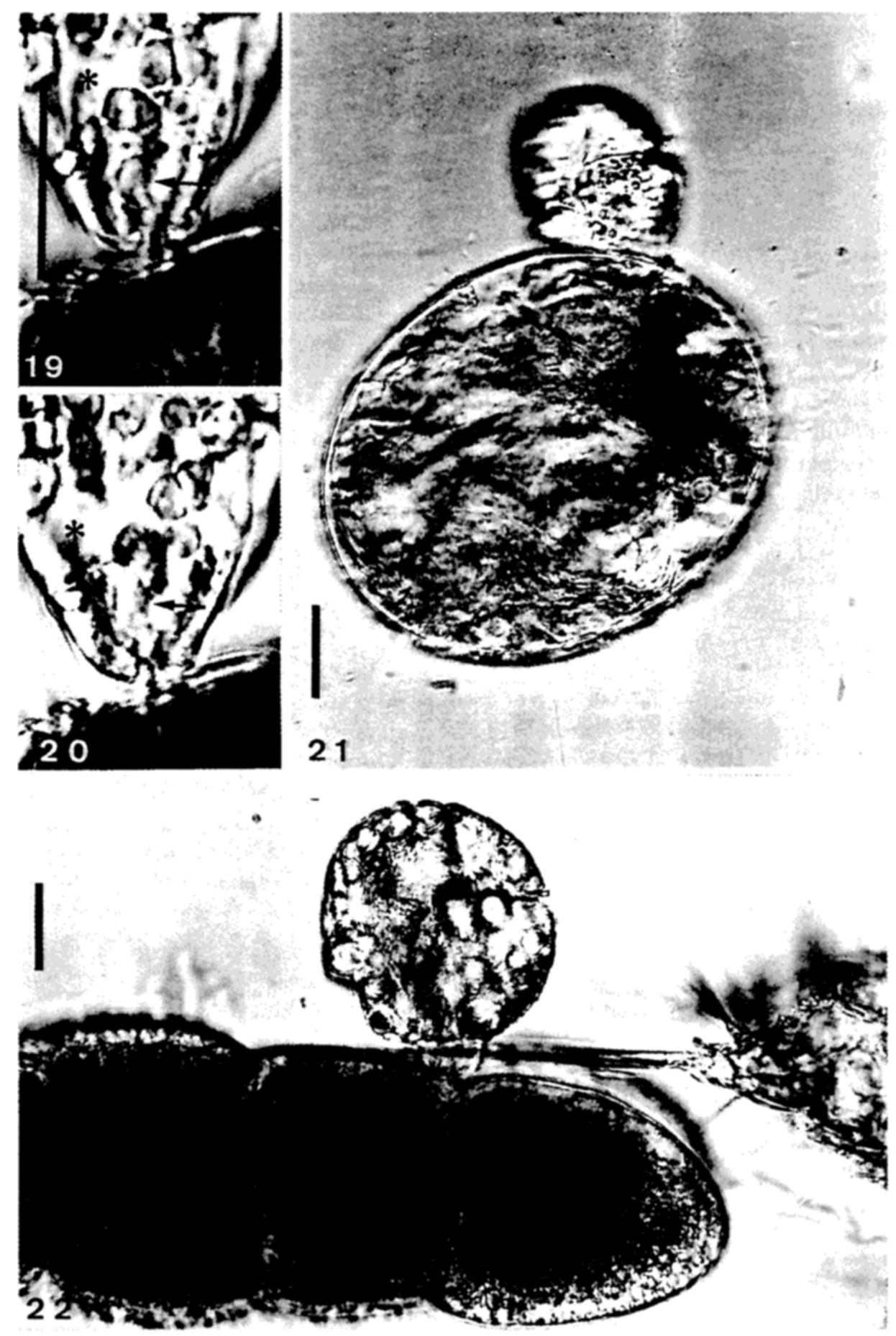

Figs 19-22. Gyrodinium undulans. Figs 19, 20. Details of food uptake: Developing food vacuole (arrow) and inconspicuous digestion vacuole (asterisk). Fig. 21. Trophont on a rotifer egg (Synchaete sp.). Fig. 22. Trophont on a harpacticoid egg (Parastenocaris sp.). Scale bars: $20 \mu \mathrm{m}$ 
capable of infecting Temora eggs at all, has still to be confirmed by using more material. Perhaps the flagellate is at best only attracted, but then unable to pierce the rigid egg wall of Temora.

When feeding on eggs, the phagopod of the flagellate is likewise short and of the same structure as developed in cells of Odontella aurita. Of course, compared with Odontella the amount of food provided by a single egg is considerably larger. Accordingly, the eggs are generally only partly emptied, even in cases of multi-infection by two or more flagellates (Fig. 24). Obviously, only fluid egg material can be transported via phagopod into the enlarging Gyrodinium trophont. When feeding has finished and the dinoflagellate detached from the egg, any remaining egg contents flow out through the phagopod that has been left behind (Fig. 24).

In one single case, in an experiment with Gyrodinium feeding on an egg of $P$. elongatus, the flagellate trophont reached a size of up to about $75 \mu \mathrm{m}$ in length and $57 \mu \mathrm{m}$ in width. This is beyond the normal size known for Gyrodinium undulans in the free-living stage from both wild and cultured material, where Odontella aurita forms the food source. When detached from the egg, the large trophont developed within four days into eight flagellates by repeated binary fission. Although not clearly recognized, because of disturbances during the experiment, a further cell division seemed to follow. Thus, most probably a 16-cell stage was the final result in this case. Resembling Syltodinium listii the 3-4 cell divisions took place in an immobile palmelloid stage, the daughter cells sticking together in a gelatinous matrix. Finally, the liberated flagellates could be again successfully fed with cells of $O$. aurita.

\section{The life cycle of Gyrodinium undulans}

Gyrodinium undulans is a cold water species, occurring in the North Frisian Wadden Sea between December and April, at water temperatures ranging from $-1^{\circ}$ up to $6^{\circ} \mathrm{C}$. The species is regularly present, when Odontella aurita as the main (or exclusive) food source is abundant. In wild samples gained from net hauls free motile stages of $G$. undulans are only occasionally met; instead emptied cells of $O$. aurita containing the phagopod walls of the dinoflagellate are often found. However, we never observed $G$. undulans attached to $O$. aurita in freshly taken net samples. This stage and likewise the subsequent phases of food uptake and vegetative multiplication could be obtained and studied only under culture conditions.

Normally, G. undulans multiplies only by one cell division, occasionally followed by a second division (Fig. 25). When copepod or rotifer eggs are offered, up to 4, 8, or 16 flagellates may result from a single feeding act (Fig. 26). How long the freshly developed flagellates take to be ready to attack new prey cells is as yet unknown.

In ageing cultures of about three to eight weeks, $O$. aurita is found in a stationary growth phase, and the cells are crowded with refractive reserve material. Then the normal development of $G$. undulans is obviously disturbed. Among the flagellates of normal size there are increasingly transparent dwarf stages of less than $20 \mu \mathrm{m}$ in length with often quick movement, or large monsters filled with storage granules. Whether we are dealing here exclusively with vegetative abnormalities, or whether perhaps sexual stages might be involved, has still to be investigated. Until now, stages showing nuclear cyclosis as an indicator for meiosis could not be found. 

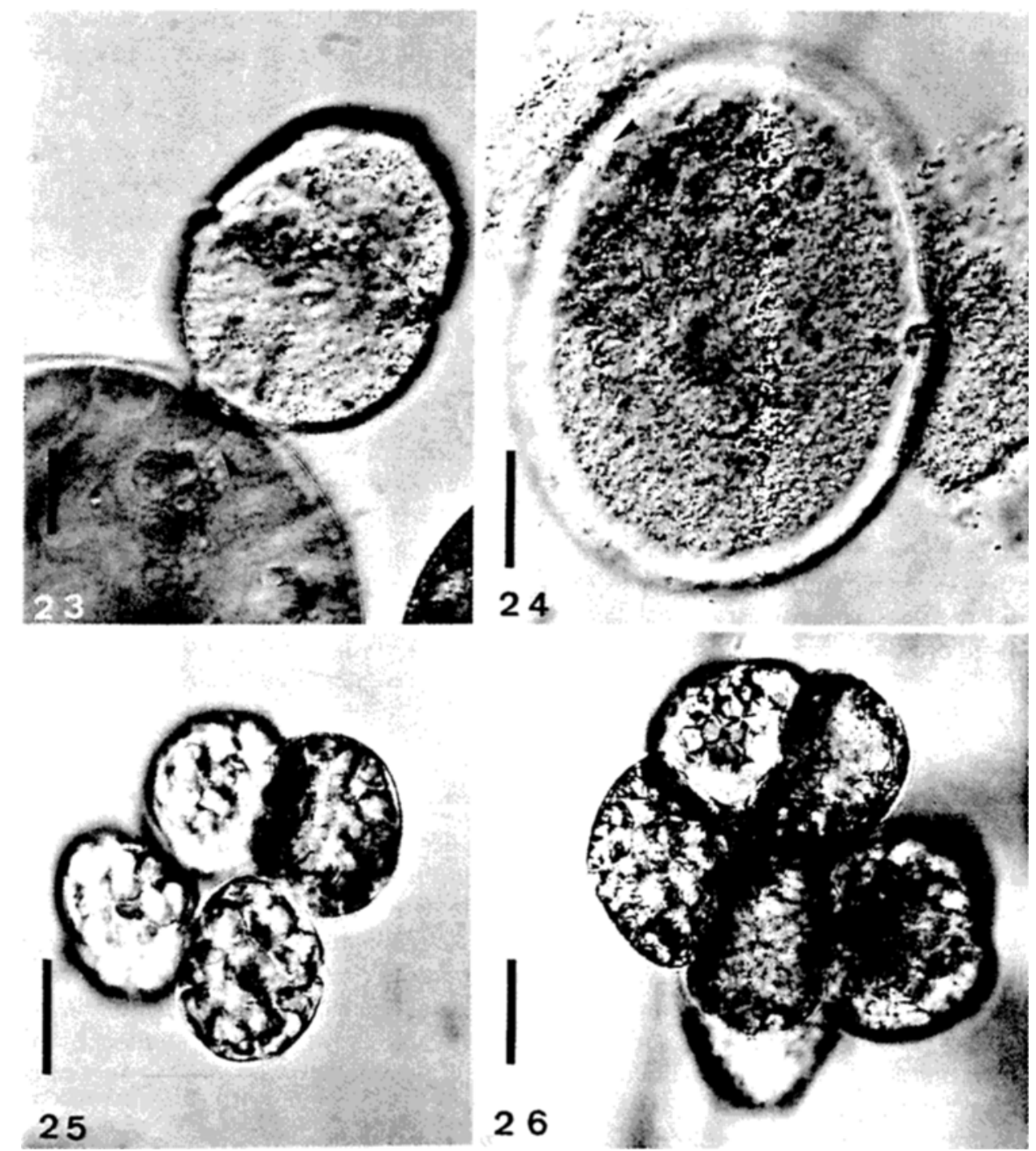

Figs 23-26. Gyrodinium undulans. Fig. 23. Trophont on a calanoid egg (Pseudocalanus elongatus), phagopod (arrowhead). Fig. 24. Two phagopods (arrowheads) left behind after double-infection of a rotifer egg (Synchaete sp.); outflowing egg contents. Fig. 25. Four flagellates derived from a trophont after feeding on Odontella. Fig. 26. Eight flagellates derived from a trophont after feeding on an egg of Pseudocalanus elongatus. Scale bars: $20 \mu \mathrm{m}$ 
A further question applies to the survival strategy of $G$. undulans during the warmer period between May and November. As yet no resting cysts could be discovered. However, immobile palmelloid stages containing up to eight cells, which are surrounded by a mucous envelope, are observed in ageing cultures. Sometimes, these cells are enclosed additionally by a thin delicate wall. Perhaps they represent temporary resting stages that will survive short periods during the winter season.

\section{DISCUSSION}

With respect to size, though stadially variable, morphology, and seasonal occurrence, the identity of the present dinoflagellate with Gyrodinium undulans is beyond doubt. It was originally described by Hulburt (1957) from Cape Cod, Massachusetts. There, it was found in the Woods Hole area (Great Pond), in January and February. Throndsen (1969) noticed the species in Norwegian coastal waters (Oslofjord) in April 1967, and later Hansen \& Larsen (1992) observed it regularly in the Northern Kattegat (Denmark) during winter and spring time. Accordingly, with respect to the available food (Odontella aurita) in the winter season, $G$. undulans may be characterized as a cold water species. This, however, does not correspond well with other records. Paulmier (1994) found G. cf. undulans in August in the Gulf of Gascogne (France). Sonneman \& Hill (1997) isolated from recent sediments of Victorian coastal waters (Australia) cyst-producing dinoflagellates, and as a result of cyst incubation experiments $G$. undulans was identified for the first time in that region. In both cases (France/Australia) the question arises, whether these species isolated from warmer waters really conform with $G$. undulans. Most probably two different taxa are involved here, which may be distinguished either as two ecological varieties of $G$. undulans, or as two separate species.

Considering the dinoflagellates that resemble G. undulans morphologically, one thinks especially of Syltodinium listii. This species feeds on copepod and rotifer eggs, and occurs during the summer months (June - August) in coastal waters (North Frisian Wadden Sea) of the North Sea (Drebes, 1988). But, although both species take up the food by a phagopod, and partly may share a similar host substrate, G. undulans only weakly accepts crustacean or rotifer eggs, and seemingly more or less when forced to under culture conditions in the laboratory. Further, their different occurrence in winter and summer, respectively, indicates the existence of two separate species. Nevertheless, final proof should be sought by comparing simultaneously both species under culture conditions. It would be interesting to see how Syltodinium behaves when faced with the food diatom Odontella aurita under low temperatures. Unfortunately, a first attempt in the course of 1997 failed, since for that year Syltodinium could not be detected in the plankton net samples taken near List/Sylt.

When a secure determination of the species has been provided, it would be interesting to investigate the ecological role it plays in the food web of the planktonic communities. That the biotic interactions of phagotrophic protozoa may considerably influence the population dynamics is meanwhile widely recognized (e. g. Bockstahler \& Coats, 1993; Kühn, 1995), though of course many details remain to be explored (Sommer, 1994). In the present case, $G$. undulans can be characterized now as a most effective feeder (predator) on $O$. aurita. This diatom constitutes one of the bloom-forming species in the annual cycle of the Wadden Sea phytoplankton. Therefore, apart from the abiotic fac- 
tors controlling the population density of Odontella, the regular impact - sometimes in epidemic dimension - of biotic factors such as $G$. undulans has to be taken into consideration.

Another generally important question applies to the food range of the phagotrophic flagellates. In the case of $G$. undulans, the prey comprises primary as well as secondary producers. When feeding on primary producers the flagellate is highly selective, accepting only the diatom $O$. aurita, but is less specific regarding secondary producers, for example, when supplied with eggs of various copepods and rotifers. Our observations made on wild material indicate that $O$. aurita is the main food source for $G$. undulans under natural conditions. It is generally suggested that the potential food (host) range, obtained from culture experiments, may be usually wider than the real or actual food (host) range of a phagotrophic (parasitic, parasitoid) flagellate from the natural environment (Drebes, 1984).

Phagotrophic dinoflagellates can engulf their prey if small enough as a whole, or they form a so-called feeding veil (pallium) which envelopes the prey, or other special organelles (feeding tubes) for food uptake are developed (Schnepf \& Elbrächter, 1992). In $G$. undulans the food passes through an antapical feeding tube into the trophont, in a similar way to that already described for Amphidinium cryophilum by Wilcox \& Wedemayer, 1991. These authors introduced the term "phagopod" for the feeding tube extending from the antapex, in contrast to the "peduncle", which emerges at the cingular-sulcal-intersection of the flagellate. Although obviously sharing the same function, both types are quite different in structure and are seemingly not homologous organelles.

A peduncle is cytoplasmatic and stiffened by microtubules, which are generally preformed as a "microtubular basket" (Kubai \& Ris, 1969), or as a single row of microtubules (Wilcox \& Wedemayer, 1984, 1991). After feeding it is retracted. A peduncle can be found, for example, in Gymnodinium fungiforme (Spero, 1982), Paulsenella spp. (Drebes \& Schnepf, 1988; Schnepf et al., 1985), and Peridiniopsis berolinensis (Wedemayer \& Wilcox, 1984). As seen below, in a few cases it is partly surrounded by a cellulosic sheath (Drebes \& Schnepf, 1988), and generally used to take up the food myzocytotically (Schnepf \& Deichgräber, 1984). The peduncle appears to be homologous with the feeding veil (pallium) as shown by Jacobson $\&$ Anderson (1992), and which is found, e. g., in species of Protoperidinium, Diplopsalis, and Oblea (Gaines \& Tailor, 1984; Jacobson \& Anderson, 1986; Elbrächter, 1991).

A phagopod is essentially a non-cytoplasmatic tube formed de novo at the onset of each feeding event, i. e. not by the protrusion of preformed microtubules. It emerges from the antapex of the dinoflagellate, and after feeding is left behind in the emptied prey cell (Wilcox \& Wedemayer, 1991). In this sense, the peduncles described for Dissodinium spp. (Drebes, 1969, 1978, 1984) and Syltodinium listii (Drebes, 1988) now have to be regarded as phagopods.

In Gyrodinium undulans the phagopod wall contains cellulose or a similar fibrillar polysaccharide. In this species the phagopod forms an appressorium at the outer surface of the Odontella aurita frustule. Like a fungal appressorium (Gäumann, 1951), it certainly counterbalances the pressure needed to pierce the cribrum of the areola, and to force the extending phagopod through the narrow areolar chamber. An analogous structure is the sheath of the peduncle in Paulsenella vonstoschii and P. kornmannii (Drebes \& Schnepf, 
1988), which likewise affixes the dinoflagellate onto the host cell frustule, and thus facilitates penetration. A sheath is lacking in P. chaetoceratis (Drebes \& Schnepf, 1988), where the perforated ("fenestrated") setae of the diatom Chaetoceros decipiens are used as entrance.

Like Paulsenella spp., also Gyrodinium undulans takes up the food by myzocytosis, a special mode of endocytosis (Schnepf \& Deichgräber, 1994). That means a sucking out of the cell contents without ingesting the plasmalemma of the prey (host) cell. The present dinoflagellate, however, shows a myzocytosis in a narrow sense only at the beginning of feeding, since food uptake continues when the plasma membrane is ruptured. This is comparable to Peridiniopsis berolinensis, where particulate food, even complete small diatoms, are ingested via a peduncle (Calado \& Moestrup, 1997).

When the phagopod of $G$. undulans crosses the porous but dense areolar pattern of the Odontella frustule, the bottle-neck is the passage through a single areola. The phagopod lumen measures here only less than $0.1 \mu \mathrm{m}$. This is obviously too narrow for the transport of larger organelles like chloroplasts, though diatom chloroplasts can be considerably deformed, as known from observations on Paulsenella (Schnepf et al., 1988). In Gyrodinium the phagopod is furnished at its mouth with a rigid fringed border, which obviously prevents the chloroplasts from getting into the phagopodal tube and plugging it.

As yet we have no information about sexual reproduction and possible formation of resting cysts (hypnozygotes?). Recently, however, interpreting the results of cyst germination experiments, Sonneman \& Hill (1997) described the occurrence of resting cysts for G. undulans. The ovoid cyst had an extremely thin and fragile wall, covered with a thin layer of mucilage. In the course of excystment, four motile cells resembling $G$. undulans were produced. The resting cysts in the sense of Sonnemann \& Hill (1997) may conform to the temporary resting stages found in our material. As for the taxonomy already mentioned above, final proof of the real identity of the species from the Wadden Sea (North Sea) with that from Victorian coastal waters (Australia) has to be awaited.

Acknowledgements. We are grateful to Ms H. Halliger for technical assistance, to Dr. M. Elbrächter for valuable discussions, and to the Deutsche Forschungsgemeinschaft for financial support.

\section{LITERATURE CITED}

Bockstahler, K. R. \& Coats, D. W., 1993. Grazing of the mixotrophic dinoflagellate Gymnodinium sanguineum on ciliate populations of Chesapeake Bay. - Mar. Biol. 116, 477-487.

Calado, A. J. \& Moestrup, Ø., 1997. Feeding in Peridiniopsis berolinensis (Dinophyceae): new observations on tube feeding by an omnivorous, heterotrophic dinoflagellate. - Phycologia 36 , 47-59.

Drebes, G., 1969. Dissodinium pseudocalani sp. nov., ein parasitischer Dinoflagellat auf Copepodeneiern. - Helgoländer wiss. Meeresunters. 19, 58-67.

Drebes, G., 1974. Marines Phytoplankton. Thieme, Stuttgart, 186 pp.

Drebes, G., 1978. Dissodinium pseudolunula (Dinophyta), a parasite on copepod eggs. - Br. phycol. J. $13,319-327$.

Drebes, G., 1984. Life cycle and host specificity of marine parasitic dinophytes. - Helgoländer Meeresunters. 37, 603-622.

Drebes, G., 1988. Syltodinium histii gen. et spec. nov, a marine ectoparasitic dinoflagellate on eggs of copepods and rotifers. - Helgoländer Meeresunters. 42, 583-591.

Drebes, G. \& Elbrächter, M., 1976. A checklist of planktonic diatoms and dinoflagellates from Helgoland and List (Sylt), German Bight. - Botanica mar. 19, 75-83. 
Drebes, G. \& Schnepf, E., 1988. Paulsenella Chatton (Dinophyta), ectoparasites of marine diatoms: development and taxonomy. - Helgoländer Meeresunters. 42, 563-581.

Elbrächter, M., 1991. Food uptake mechanisms in phagotrophic dinoflagellates and classification. In: The biology of free-living heterotrophic flagellates. Ed. by D. J. Patterson \& J. Larsen. Clarendon Press, Oxford, 303-312.

Gaines, G. \& Taylor, F. J. R., 1984. Extracellular digestion in marine dinoflagellates. - J. Plankt. Res. 6, 1057-1061.

Gäumann, E., 1951. Pflanzliche Infektionslehre. - Birkhäuser, Basel, 681 pp.

Jacobson, D. M. \& Anderson, D. M., 1986. Thecate heterotrophic dinoflagellates: feeding behaviour and mechanisms. - J. Phycol. 22, 249-258.

Jacobson, D. M. \& Anderson, D. M., 1992. Ultrastructure of the feeding apparatus and myonemal system of the heterotrophic dinoflagellate Protoperidinium spinulosum. - J. Phycol. 28, 69-82.

Kubai, D. F. \& Ris, H., 1969. Division of the dinoflagellate Gyrodinium cohnii (Schiller). A new type of nuclear reproduction. - J. Cell Biol. 40, 508-528.

Hansen, G. \& Larsen, J., 1992. Dinoflagellater i danske farvande. In: Plankton i de indre danske farvande. Ed. by H. A. Thomsen. Miljøministeriet, København, 45-155. (Havforskning fra Miljøstyrelsen, $\mathrm{Nr}$ 11.)

Hulburt, E. M., 1957. The taxonomy of unarmored Dinophyceae of shallow embayments on Cape Cod, Massachusetts. - Biol. Bull. mar. biol. Lab., Woods Hole 112, 196-219.

Kühn, S., 1995. Untersuchungen zum Befall von Phytoplankton durch parasitoide Protisten (Nordsee). Diss., Univ. Bremen, $150 \mathrm{pp}$.

Paulmier, G., 1994. Les dinophycées pelagiques et benthiques du Golfe de Gascogne Sud de la Bretagne à Arcachon. - Annls Soc. Sci. nat. Charente-Marit., 8, 289-357.

Schnepf, E. \& Deichgräber, G., 1984. "Myzocytosis", a kind of endocytosis with implications to compartmentation in endosymbiosis: observations in Paulsenelld (Dinophyta). - Naturwissenschaften $71,218-219$.

Schnepf, E. \& Elbrächter, M., 1992. Nutritional strategies in dinoflagellates. A review with emphasis on cell biological aspects. - Eur. J. Protistol. 28, 3-24.

Schnepf, E.. Deichgräber, G. \& Drebes, G., 1985. Food uptake and the fine structure of the dinophyte Paulsenella sp., an ectoparasite of marine diatoms. - Protoplasma 124, 188-204.

Schnepf, E., Meier, R. \& Drebes, G., 1988. Stability and deformation of diatom chloroplasts during food uptake of the parasitic dinoflagellate Paulsenella (Dinophyta). - Phycologia 27, 283-290.

Schöne, H. K. \& Schöne, A., 1982. A weakly enriched sea-water medium for ecological studies on marine plankton algae, some examples of its application. - Botanica mar. 25, 117-122.

Sommer, U., 1994. Planktologie. Springer, Berlin, $274 \mathrm{pp}$.

Sonneman, J. A. \& Hill, D. R. A., 1997. A taxonomic survey of cyst-producing dinoflagellates from Recent sediments of Victorian coastal waters, Australia. - Botanica mar. 40, 149-177.

Spero, H. J., 1982. Phagotrophy in Gymnodinium fungiforme (Pyrrophyta): the peduncle as an organelle of ingestion. - J. Phycol. 18, 356-360.

Throndsen, J., 1969. Flagellates of Norwegian coastal waters. - Nytt Mag. Bot. 16, 161-216.

Wedemayer, G. J. \& Wilcox, L. W., 1984. The ultrastructure of the freshwater, colorless dinoflagellate Peridiniopsis berolinense (Lemm.) Bourelly (Mastigophora, Dinoflagellida). - J. Protozool. $31,444-453$.

Wilcox, L. W. \& Wedemayer, G. J., 1984. Gymnodinium acidotum Nygaart (Pyrrophyta), a dinoflagellate with an endosymbiotic cryptomonad. - J. Phycol. 20, 236-242.

Wilcox, L. W. \& Wedemayer, G. J., 1991. Phagotrophy in the freshwater, photosynthetic dinoflagellate Amphidinium cryophilum. - J. Phycol. 27, 600-609. 